УДК 342.95

DOI https://doi.org/10.32849/2663-5313/2020.12.27

\title{
Роман Шаповал,
}

докт. юрид. наук, професор,

професор кафедри адміністративного права та адміністративної діяльності

Начіонального юридичного університету імені Ярослава Мудрого

\author{
Христина Солнщева, \\ канд. юрид. наук, доиент, \\ доцент кафедри адміністративного права та адміністративної діяльності \\ Начіонального юридичного університету імені Ярослава Мудрого
}

\section{ОПТИМІЗАЦІЯ АДМІНІСТРАТИВНИХ ПРОЦЕДУР КАДРОВОЇ ПОЛІТИКИ НАЦІОНАЛЬНОЇ ПОЛІЦЇ УКРАЇНИ}

Стаття присвячена вибору найбільш доцільних шляхів оптимізації адміністративних прочедур з питань кадрової політики в органах Національної полічії України, ураховуючи низку нагальних проблем, таких як низький рівень освіти за професійною спрямованістю, високий рівень корумпованості, низький авторитет і рівень довіри населення до прачівників органів Начіональної полічій України тощо. Розглянуто визначення «кадрова політика» й основні форми кадрового забезпечення Начіональної поліиії України, а також нормативно-правове регулювання ивого питання. Проаналізована Стратегія розвитку органів системи Міністерства внутрішніх справ на період до 2020 року в питанні кадрового забезпечення органів Начіональної полічії, зокрема їі основна мета й напрями реалізачії. Під час дослідження кадрової політики Національної полічії в аспекті встановлення компетениій, визначення завдань, повноважень, обов'язків кадрового складу та ступеня відповідальності прачівників підрозділів полічї ключову роль відіграє принщип прозорості, передбачений достатній рівень відкритості в прочесі діяльності полічейських підрозділів у питаннях дотримання прав і свобод людини для громадського контролю, а також державного й міжнародного моніторингу. Розглянуто здобутки полічейських реформ і досвід роботи з кадрами в органах поліиії в Грузї, Естонії та Латвії. У статті автори пропонують упровадження ефективних напрямів оптимізаиї процедур кадрового забезпечення органів Національної полічії України, зокрема більш прозорий і відкритий проиес добору персоналу, підвищення кваліфікачії та професіоналізму правоохорониів шляхом їх підготовки й перепідготовки, підвищення якості умов пращі, а також удосконалення законодавства, яке регулює діяльність правоохоронних органів. На прикладі поліиейських реформ вищезазначених країн автори зробили висновок, що нестача кваліфікованих кадрів не завжди єперепоною для побудови якісно нового поліиейського корпусу; звільнення за корупиійні правопорушення також є доцільним; нагальним є проведення реструктуризацї̈ й удосконалення наявних органів Національної полічіӥ і створення спеціалізованих шкіл, які б готували нові кваліфіковані кадри.

Ключові слова: кадрова політика, адміністративні процедури, Національна поліція, кадрове забезпечення, органи Національної поліції України.

Постановка проблеми. Питання кадрового забезпечення органів Національно Поліції України є одним із найважливіших для вдосконалення її функціонування. Відповідно до Закону України «Про Національну поліцію», Національна поліція України визначається як центральний орган виконавчої влади, який служить суспільству шляхом забезпечення охорони прав і свобод людини, протидії злочинності, підтримання публічної безпеки й порядку [4].

Отже, законодавець наголосив на тому, що органи Національної поліції відіграють провідну роль у забезпеченні функціону- вання держави та суспільства й підтриманні правопорядку. Нині процедура кадрового забезпечення органів не є досконалою, виходячи із цього, питання оптимізації адміністративних процедур з питань кадрової політики в Національній поліції України набуває неабиякого значення, особливо в умовах сучасного стану розвитку держави.

Зважаючи на те що проблема оптимізації кадрового забезпечення в органах Національної поліції постала нещодавно, то ця тема не $є$ дослідженою науковцями. Однак варто виокремити деяких правників, які досліджували це та суміжні питання, такі як 
В. Авер'янов, О. Бандурка, А. Комзюк, О. Проневич, А. Танько, В. Тетеря, А. Потопальський, П. Маннінг, Д.Е. Барлоу, М.Х. Барлоу, M.X. Мyp і багато інших науковців. Однак це питання потребує подальшого наукового доопрацювання, оскільки адміністративні процедури з кадрового забезпечення зараз перебувають у процесі реформування й зазнають досить динамічних змін. Отже, обрана тема потребує подальшої наукової розробки.

Нині не вирішеною проблемою є обрання найбільш оптимальних і досконалих шляхів оптимізації кадрового забезпечення органів Національної поліції, їх оптимізація та відкритість. Діяльність Національної поліції зазнала чималих змін у процесі реформування, включаючи й кадровий корпус. Однак процедури кадрового забезпечення сьогодні не $є$ досконалими, а тому потребують подальшого доопрацювання.

Метою статті є системний аналіз можливих адміністративних процедур оптимізації кадрового забезпечення та нормативноправової бази, яка регулює це питання, а також унесення пропозицій щодо вдосконалення законодавства із цього питання

з урахуванням досвіду іноземних країн.

Виклад основного матеріалу.

1. Поняття й загальна характеристика кадрового забезпечення органів Національної поліції

Із прийняттям Закону України «Про Національну поліцію» закладено фундамент реформ щодо створення сучасної правоохоронної системи, яка дасть змогу відновити рівень довіри суспільства до правоохоронних органів. Бездіяльність окремих працівників органів внутрішніх справ на Сході України, яка стала одним із факторів, які призвели до дестабілізації ситуації в країні, висока корумпованість на всіх ланках і в структурах внутрішньо кадрового забезпечення системи MBC - усе це вказує на критичну потребу в змінах.

У зв'язку із цим запровадження прозорості й відкритості в процедурах відбору кадрів до органів Національної поліції України, на наш погляд, є необхідним та одним із першочергових завдань.

Нині існує низка проблем, які прямо чи опосередковано стосуються забезпечення кадрами органи Національної поліції України. По-перше, це низький рівень освіти за професійною спрямованістю, адже професія поліцейського є досить складною та потребує багато спеціальних знань i навичок для ефективного розслідування правопорушень тощо.
Наступною проблемою є високий рівень корумпованості, починаючи 3 прийняття поліцейського на роботу. При такому рівні корупції не можна вести мову про ефективну діяльність органів Національної поліції України, тому повне викоренення корупції є одним із ключових питань. До того ж, окрім корупційних правопорушень, є багато випадків, коли працівники поліції вчиняють злочини прямо під час виконання своїх повноважень. Це суттєво підриває авторитет поліцейських і зменшує рівень довіри населення до працівників органів Національної поліцій України.

Наступним важливим питанням $€$ кадрове планування, оскільки таке планування не є характерним у нашій державі. Планування кадрового забезпечення є важливим, щоб не було нестачі кваліфікованих кадрів. Необхідність такого планування потрібне, щоб не створювалося багато підрозділів органів поліції, які дублюють функції один одного, що, урешті-решт, призводить до зниження якості й ефективності роботи.

Реформою Національної поліції України визначено один із пріоритетних напрямів удосконалення діяльності поліції в Україні - оптимізація кадрових процедур у Національній поліції України з метою забезпечення ефективного відбору, підготовки та навчання кадрів, проходження ними служби, запровадження оптимальної системи мотивації, просування по службі, звільнення тощо. Мета такої оптимізації кадрових процедур - забезпечення якісного укомплектування Національної поліції України кваліфікованими та професійними кадрами, які були б адаптовані до викликів сучасності, якісно виконували покладені на них завдання, що має призвести до зростання рівні довіри населення органами Національної поліції України та забезпечить дотримання правопорядку, а також прав і свобод людини та громадянина. На жаль, наступні позитивні зміни не відбуваються повною мірою, що негативно відбивається на загальному функціонуванні органів поліції.

Нині науковці не дійшли згоди щодо єдиного визначення поняття «кадрова політика», трактують це поняття по-різному. Далі визначимо найбільш доцільні поняття.

Наприклад, С. Дембіцька зазначає, що кадрова політика - це загальний курс, а також послідовна діяльність держави щодо формування вимог до службовців, їх добору, підготовки й раціонального використання з урахуванням стану та перспектив розвитку державного апарату, прогнозів щодо кількісних і якісних потреб у кадрах [3]. 
На думку В. Сокуренка, кадрова політика являє собою закономірну реалізацію певних заходів, які, зокрема, передбачені нормативно-правовими актами. Така діяльність спрямована на формування стабільного висококваліфікованого персоналу в органах поліції, тобто його підбір, підготовку та розстановку, а також забезпечення професійного й особистого розвитку [11].

На нашу думку, найбільш доцільним $€$ визначення кадрової політики, надане К. Бугайчуком, який зазначає, що кадрова політика за своєю сутністю є нормативно закріпленою сукупністю принципів, правил, норм, поглядів і рекомендацій, спрямованих на регулювання загальної організації роботи з персоналом у рамках певної сфери суспільного життя, державного органу, відокремленого підрозділу або господарського підприємства [2].

Основними формами кадрового забезпечення Національної поліції України є:

1) відбір поліцейського на посаду (кандидат складає тест професійного спрямування, тест на загальні вміння та навички, психологічний тест, проходить співбесіду, можливе також тестування на поліграфі);

2) медичні обстеження кандидатів на поліцейську службу (кандидат проходить профілактичний огляд, перевірку простої зорово-моторної реакції, складає тест на реакцію на рухомий об'єкт);

3) прийняття та призначення кандидата на службу в Національній поліції України;

4) просування поліцейського по службі (поліцейський складає тест загальних навичок, тест за конкретним напрямом роботи; проходить тест-оцінку знання професійної етики);

5) оцінювання та контроль діяльності поліцейського під час перебування на займаній посаді (проходження перевірки фізичної підготовки, атестаційний лист);

6) громадський контроль за кадровим забезпеченням і діяльністю Національної поліції [10].

До цих форм також доцільно додати:

1) запровадження ефективної системи навчання кандидатів (курсантів, студентів) на службу в поліції;

2) підвищення кваліфікації поліцейських;

3) запобігання корупційним проявам при прийнятті на службу та профілактика протидії корупції в подальшій діяльності поліцейських.

2. Основні напрями оптимізації адміністративних процедур з питань кадровоі політики

В умовах євроінтеграції одним із зобов'язань, покладених на нашу дер- жаву, є приведення законодавства України у відповідність до європейських стандартів. У царині діяльності поліції варто взяти за орієнтир практику Свропейського суду з прав людини, а також положення Європейського кодексу поліцейської етики, досвід зарубіжних країн, де поліцейська система успішно функціонує вже тривалий час [8].

Одним із пріоритетів Стратегії розвитку органів системи Міністерства внутрішніх справ на період до 2020 року є формування стабільного та високопрофесійного кадрового складу органів системи МВС, який здатний належно реагувати на виклики й загрози у визначених сферах. Варто зазначити, що підвищення ефективності кадрових процедур є одним із напрямів Стратегії державної кадрової політики на 2012-2020 pр., що передбачає вирішення в т. ч. таких важливих завдань:

1) розроблення національної системи оцінювання якості освіти;

2) формування узгодженої системи оцінювання отриманих знань, умінь і навичок за результатами підготовки, перепідготовки та підвищення кваліфікації згідно з вимогами, необхідними для виконання роботи за певною професією, посадою, а також формування системи оцінювання під час добору фахівців;

3) запровадження системи безперервного професійного навчання кадрів;

4) створення механізму професійної адаптації новопризначених працівників;

5) запровадження періодичного оцінювання результатів професійної діяльності працівників тощо [5].

Поряд із тим, що необхідно підвищувати рівень професіоналізму нових поліцейських, працівники кадрової служби також мають відповідати певним новим вимогам, зокрема, окрім спеціальної підготовки, працівники кадрової служби повинні володіти знаннями права, психології, педагогіки, соціології та економіки. Кадровій службі потрібно проводити планування кар'єри державних службовців, створювати програму розвитку персоналу. Процеси добору персоналу мають базуватися на принципі інформатизації, що буде цілком відповідати сучасним вимогам суспільства, для цього працівникам кадрової служби необхідне відповідне технічне оснащення.

Структура кадрової служби має передусім базуватися не на загальній чисельності робітників, а на покладених на поліцейський орган завданнях і функціях.

Під час дослідження кадрової політики Національної поліції в аспекті встановлення компетенцій, визначення завдань, повно- 
важень, обов'язків кадрового складу та ступеня відповідальності працівників підрозділів поліції потрібно наголосити на тому, що Національна поліція та ії̈ окремі органи й підрозділи, відповідно до норм сучасного законодавства, повинні діяти згідно з принципом прозорості. Цим принципом передбачений достатній рівень відкритості в процесі діяльності поліцейських підрозділів у питаннях дотримання прав і свобод людини для громадського контролю, а також державного й міжнародного моніторингу [9].

Становлення та розвиток Національної поліції вимагає виховання й підготовки нової когорти правоохоронців, які будуть дійсно новим поколінням, із новими прогресивними поглядами, новим ставленням до роботи, нетерпимістю до корупційних проявів, світогляд яких буде базуватися на основі загальнолюдських цінностей, принципах гуманізму та демократії, з усвідомленням свободи й прав людини та громадянина як найважливішого здобутку суспільства.

Освіта та професійна підготовка нового покоління правоохоронців потребують удосконалення й реформування з обов'язковим включенням таких складників:

- реорганізація всіх закладів вищої освіти, що підпорядковані Міністерству внутрішніх справ;

- створення мережі закладів професійної підготовки (так званих поліцейських шкіл), які б здійснювали первинну підготовку поліцейських тільки призначених на посаду, а також і перепідготовку вже працюючих правоохоронців [6].

Отже, на основі проведеного аналізу автори пропонують такі можливі напрями оптимізації кадрового забезпечення органів Національної поліції України:

- необхідно організувати відбір і розстановку кадрів в органах внутрішніх справ на кожному рівні задля оптимізації якісного складу кадрів органів внутрішніх справ i забезпечення якісного та професійного виконання правоохоронцями покладених на них завдань;

- спростити й зробити відкритим і прозорим процес кадрового забезпечення й управління кадрами, модернізувати та запровадити інформатизацію управління кадрами, це, зокрема, підвищить довіру громадськості до правоохоронних органів;

- реформувати системи навчальних закладів, які готують кадри для органів поліції, з метою більш якісного та професійного навчання кадрів, здатних адаптуватися до сучасних потреб і запитів суспільства;

- забезпечити можливість підвищення кваліфікації вже працюючих правоохоронців;
- закріпити оптимальні умови праці, у т. ч. режиму робочого часу й відпочинку, оплати праці, трудової дисципліни, охорони й безпеки праці, щоб професія поліцейського була привабливою для професіоналів і не виникало проблеми нестачі кваліфікованих кадрів;

- i, звичайно, усі описані вище напрями неможливо впровадити без відповідного нормативно-правового регулювання, тобто законодавча база також має бути вдосконалена й адаптована під європейські стандарти та сучасні виклики суспільства. На законодавчому рівні необхідно, зокрема, оптимізувати процедури розподілу навантаження й повноважень між органами та підрозділами поліції та їх працівниками, посилити контроль за дотриманням штатної дисципліни в органах поліції, а також визначити процедуру притягнення до відповідальності всіх категорій працівників правоохоронних органів, а також визначити можливі заходи впливу на порушників.

С. Стеценко наводить таку класифікацію адміністративних процедур:

1) нормативні процедури;

2) засновні процедури;

3) правоохоронні процедури;

4) порядок реєстрації;

5) сертифікаційні процедури;

6) контрольні та наглядні процедури [15].

На нашу думку, безпосередньо у функціонуванні Національної поліції України важливу роль відіграють нормативні, правоохоронні, сертифікаційні, контрольно-наглядні та сервісно-консультаційні адміністративні процедури [14]

3. Міжнародний досвід оптимізації адміністративних процедур із питань кадрової політики в полічіі

Міжнародні та національні експерти вказують на значний прогрес у реформуванні української поліції. Лише за два роки Україні вдалося здійснити пакет реформ, який упровадив багато європейських країн протягом десяти років. Реформа поліції вважається однією з найбільш успішних і динамічних з усіх реформ у державі.

У багатьох країнах світу (Велика Британія, Чехія,Бельгія, Данія, Німеччина, Естонія, Латвія, Литва, США тощо) місцева поліція розглядається населенням як організація, основою якої є ідея спільної відповідальності й безпеки; яка має місію і стратегію запобігання злочинності на конкретній території; де профілактична робота стоїть на високому рівні та рівноцінна розслідуванню вже скоєних правопорушень [7].

У вищеназваних країнах зберігається дуже високий рівень довіри населення до 
правоохоронних органів загалом і поліцейських зокрема, яких уважають професіоналами в правоохоронній сфері, бо правоохоронці добросовісно та якісно виконують покладені на них функції з дотримання правопорядку. Також необхідно зазначити, що населення цих країн $є$ широко поінформованим у питанні діяльності правоохоронних органів, їхньої діяльності, функцій та обов'язків.

Після проголошення декларації «Про відновлення державної незалежності Латвійської Республіки» судова реформа визначена одним із пріоритетних завдань Латвії. У державі створена нова система правоохоронних органів, у розвитку яких визначено три напрями:

1) деякі правоохоронні органи, які, по суті, не відповідали державному устрою, припинили своє існування;

2) створені нові, раніше не існуючі правоохоронні установи, які необхідні для зміцнення держави;

3) ті правоохоронні органи, які вже були створені й продовжили функціонувати після проголошення незалежності, бо без них неможливе функціонування та розвиток правової демократичної держави, пройшли крізь реформування, зокрема такі органи проходили процеси реструктуризації та вдосконалення.

Кінцева мета таких змін - створення правової та демократичної держави [13].

В Естонії значну увагу було приділено освіті кадрів, які мали на меті працювати в правоохоронних органах, створено школу поліції - навчальний заклад під юрисдикцією Міністерства внутрішніх справ та Управління поліції, який готує молодших і старших поліцейських на основі середньої освіти.

Отже, проблема забезпечення органів поліції кваліфікованими кадрами вирішена шляхом створення спеціалізованого навчального закладу, підпорядкованого МВС.

Існувала ще одна проблема - організація управління сімнадцятьма територіальними підрозділами поліції, які входили до складу Департаменту поліції з розслідування кримінальних злочинів. Ця проблема вирішена організаційною реформою цих підрозділів, яка проводилася в рамках адміністративнотериторіальної реформи [13].

У Грузії в короткий термін проведена структурна реформа МВС. Одні міліцейські відомства ліквідовані, інші об'єднані. Передусім скасування піддалася найбільш корумпована структура - ДАІ.

Чотирнадцять тисяч співробітників автоінспекції були звільнені в один день, а протягом наступних декількох місяців, поки формувався новий підрозділ, за порядком на дорогах у Грузії ніхто не стежив.

Загалом протягом двох років із 85 тисяч старих співробітників МВС звільнено 75 тисяч, тобто оновився майже весь поліцейський корпус, однак такі радикальні реформи принесли свої результати.

Реформа загалом базувалася на принципі повної нетерпимості до корупції, а не обмежувалася звільненням поліцейських і прийняттям на роботу нових кадрів. Будьякі корупційні прояви одразу придушувалися, держава взяла повний контроль над ними, зокрема навіть призначалися «офіцери під прикриттям» для контролю за тим, щоб поліцейські прямували до встановлених правил. Рядовий співробітник міг працювати в парі з офіцером під прикриттям і ніколи про це не дізнатися, якщо тільки він не порушував правил.

Також постійно проводилися вибіркові перевірки задля контролю за виконанням усіх внутрішніх розпоряджень поліції. Співробітник під прикриттям міг подати заяву 3 приводу домашнього скандалу в поліцейську дільницю, щоб проконтролювати, як на нього відреагують. Інший такий співробітник міг їздити вночі з вимкненими фарами. Коли його зупиняли, він пояснював, що їде відремонтувати фари й пропонував гроші. Поліцейські, викриті в хабарництві, звільнялися. Такий підхід наочно демонстрував новоприбулим поліцейським, наскільки серйозно міністерство ставиться до дотримання кодексу й етичних норм поведінки поліцейських [12].

Нова професійна поліція була орієнтована на забезпечення правопорядку, надання якісних послуг громадянам, а також забезпечення дотримання прав і свобод громадян. Через велику корумпованість старого поліцейського корпусу майже весь він був звільнений, з'явилося багато вакантних місць, однак необхідні були лише такі кадри, які мали нові професійні якості й нове ставлення до роботи. Потрібна була велика кількість професіоналів, нетерпимих до будьяких корупційних проявів. Для залучення найбільш талановитих фахівців уряд найняв на службу значну кількість нових поліцейських серед випускників університетів і юридичних факультетів, які мали скласти іспит. Нові співробітники проходили прискорену підготовку з метою освоєння основ поліцейської служби, внутрішніх правил і спілкування з громадянами. Для всієї країни цієї кількості поліцейських було недостатньо, тому до роботи були підключені інші правоохоронні органи, які були задіяні на рівні регіонів країни. Знову найняті патрульні 
поліцейські пройшли шестимісячний випробувальний термін.

Згодом у патрульну службу стали наймати випускників середніх шкіл, а базова підготовка була збільшена 3 двох тижнів до двох місяців з періодичними курсами підвищення кваліфікації. Як й очікувалося, деяких із раніше прийнятих на службу патрульних довелося замінити: одних за хабарі або порушення внутрішніх правил, іншим же їх становище з блискучим автомобілем і красивою формою запаморочила голови, чимало офіцерів звільнено за перевищення повноважень [1].

Отже, на прикладі Грузії ми можемо наочно побачити, що навіть нестачу кваліфікованих кадрів можна подолати, треба лише продовжувати будувати новий поліцейський корпус на принципі нетерпимості до корупції, бо інакше корупцію не подолати. Недостатньо просто набрати нові кадри, необхідно перевірити їній професіоналізм і нетерпимість до корупції.

\section{Висновки}

В умовах євроінтеграції Україна має провести чимало реформ задля адаптації до європейських стандартів. Одна 3 таких реформ - реформа правоохоронних органів. Ця реформа вже дала велику кількість позитивних результатів, однак нині ще зарано говорити про досконалість її впровадження. Зокрема, потребують реформування й оптимізації адміністративні процедури кадрового забезпечення.

Авторами пропонується запровадження конкретних напрямів оптимізації кадрових процедур, зокрема більш прозорий і відкритий процес добору персоналу, підвищення кваліфікації та професіоналізму правоохоронців шляхом їх підготовки й перепідготовки, підвищення якості умов праці, а також удосконалення законодавства, яке регулює діяльність правоохоронних органів.

На прикладі поліцейської реформи Грузії можна зробити висновок, що нестача кваліфікованих кадрів не завжди є перепоною для побудови якісно нового поліцейського корпусу. Цілковите викоренення корупції $€$ першим кроком у такому реформуванні. Звільнення за корупційні правопорушення також є доцільним, оскільки корупційні прояви можуть поширюватися лише у випадках, коли залишаються безкарними. Саме така нетерпимість до корупції запроваджена в Грузії, що й дало змогу успішно провести поліцейську реформу.

3 досвіду Латвії необхідно зробити висновок, що в Україні є доцільним прове- дення реструктуризації та вдосконалення наявних органів Національної поліції.

Досвід Естонії вказує на важливість професійної освіти поліцейського, тому в Україні необхідно створення спеціалізованих шкіл, які б готували нові кваліфіковані кадри.

3 огляду на міжнародний досвід, запровадження вищезазначених заходів сприятиме оптимізації адміністративних процедур кадрового забезпечення в органах національної поліції України, а також зробить поліцейську діяльність максимально наближеною до європейських стандартів.

\section{Список використаних джерел:}

1. Борьба с коррупцией в сфере государственных услуг: Хроника реформ в Грузии. URL: chrome-extension://oemmndcbldboiebf nladdacbdfmadadm/http://documents1.worldbank. org/curated/pt/330531468274499014/pdf/664490 PUB0RUSS0Georgia0Book0Russian.pdf.

2. Бугайчук К. Кадрова політика та кадрове забезпечення публічного адміністрування в органах Національної поліції.

3. Дембіцька С. Кадрове забезпечення органів державної влади в Україні. Вісник Наиіонального університету «Львівська політехніка». Серія «Юридичні науки». 2014. № 782. С. 33-38. URL: http://nbuv.gov.ua/UJRN/vnulpurn_2014_782_.

4. Про Національну поліцію : Закон $\overline{\mathrm{У}}$ країни. Відомості Верховної Ради України (ВВР). 2015. № 40-41. Ст. 379. URL: https://zakon.rada.gov.ua/ laws/show/580-19\#Text.

5. Про затвердження плану заходів 3 реалізації Стратегії розвитку органів системи Міністерства внутрішніх справ на період до 2020 року : Розпорядження Кабінету Міністрів України від 21 серпня 2019 р. № 693-p. URL: https://zakon.rada.gov.ua/laws/show/693-2019$\%$ D1\%80\#Text $\backslash$.

6. Потопальський А.В. Удосконалення адміністративних процедур та організаційних засад професійної підготовки поліцейських в Україні. Право і безпека - Право и безопасность - Lат аnd Safety. 2019. № 2 (73). URL: http://pb.univd.edu. ua/index.php/PB/article/view/255/204.

7. Солнцева Х.В. Деякі питання організації поліцейської діяльності. Право та інновації. 2017. № 1 (17).

8. Солнцева Х.В. Поняття «поліцейська діяльність» в Україні та США. Право та інноваиіі. 2016. № 1 (13).

9. Танько А.В. Стратегія кадрової політики Національної поліції України у контексті оновлення адміністративно-правових засад захисту прав і свобод людини. Вісник ХНУВС - Bulletin of KhNUIA. 2020. № 2 (89). URL: http://visnyk.univd. edu.ua/index.php/VNUAF/article/view/273/259.

10. Тетеря В.М. Адміністративно-правові засади кадрового забезпечення Національної поліції України на регіональному рівні : автореф. дис. ... канд. юрид. наук. Харків, 2018. 
11. Управління органами Національної поліції України : підручник / за заг. ред. докт. юрид. наук, доц. В.В. Сокуренка ; МВС України, Харків. нац. ун-т внутр. справ. Харків, 2017. 580 с.

12. Федоровская И. Реформы в Грузии - что дальше? URL: https://www.imemo.ru/ files/File/magazines/rossia_i_novay/2012_03/ IFED_reforms.pdf.

13. Problematic Issues of the Administrative and Legal Status of the Police in the Baltic States
(Lithuania, Latvia, Estonia) / R. Shapoval, I. Bytiak, N. Khrystynchenko, Kh. Solntseva. ASERS Publishing. 2018. Volume IX. Issue 1 (31.

14. Solntseva K.V., Kurakin O.M., Chanysheva A.R., Sobakar A.O. Classification of Personnel Procedures in the National Police of Ukraine. Amazonia Investiga. 2020. Volume 9 Issue 28

15. Stetsenko S.G. Administrative Law of Ukraine : Textbook. K. : Atica, 2008. 624 p.

Roman Shapoval, Khrystyna Solntseva. Optimization of administrative procedures of the personnel policy of the National Police of Ukraine

The article is devoted to the choice of the most appropriate ways to optimize administrative procedures on personnel policy in the National Police of Ukraine, considering several pressing issues such as low level of education, high level of corruption, low authority and public confidence in the National Police of Ukraine. The definition of "personnel policy" and the main forms of staffing of the National Police of Ukraine, as well as the legal regulation of this issue are considered. The Strategy for the development of the system of the Ministry of Internal Affairs for the period up to 2020 in the issue of staffing of the National Police, its main purpose and areas of implementation are analysed. In the study of the personnel policy of the National Police in terms of establishing competencies, defining tasks, powers, responsibilities of staff and the degree of responsibility of police officers, the key role is played by the principle of transparency, sufficient level of openness in policing for public control, as well as state and international monitoring. The achievements of police reforms and the experience of working with personnel in the police in Georgia, Estonia and Latvia are considered. In the article, the authors propose the introduction of effective ways to optimize the procedures for staffing the National Police of Ukraine, in particular, a more transparent and open process of personnel selection, training and professionalism of law en forcement of ficers through training and retraining, improving working conditions as well as legislation regulating activities of the law enforcement agencies. On the example of police reforms in the above mentioned countries, the authors concluded that the lack of qualified personnel is not always an obstacle to building a qualitatively new police corps; dismissal for corruption offenses is also appropriate; it is urgent to restructure and improve the existing bodies of the National Police and to create specialized schools that would train new qualified personnel.

Key words: personnel policy, administrative procedures, National Police, staffing, bodies of the National Police of Ukraine. 